\title{
Economic Performance or Electoral Necessity? Evaluating the System of Voluntary Income to Political Parties ${ }^{1}$
}

Justin Fisher (London Guildhall University)

\begin{abstract}
Whilst the public funding of political parties is the norm in Western democracies, its comprehensive introduction has been resisted in Britain. Political and electoral arrangements in Britain require parties to function and campaign on a regular basis, whilst their income cycles largely on general elections. This article shows that the best predictor of party income is the necessity of a well-funded general election campaign rather than party performance. As a result, income can only be controlled by parties to a limited degree, which jeopardises their ability to determine their own financial position and fulfil their functions as political parties.
\end{abstract}

The financing of political parties has been an increasingly important feature of British politics during the past fifteen years. Three major examinations of the system have taken place. The 1984 Trade Union Act challenged the basis of trade union political activity (Fisher, 1992). It required unions holding political funds to review this by regularly balloting their members. In both rounds of ballots to date (1985-6 and 1995-6), members supported the continuation of their union's political funds. In 1993-4, the Home Affairs Select Committee investigated whether parties' income were adequate for their needs and whether there was therefore a case for additional funds to made available by the state. The report concluded that the case for additional funds was not compelling. Finally, in 1998, the Committee on 
Standards in Public Life (often known as the Neill Committee after its chair, Lord Neill) conducted a very extensive review of many aspects of British party finance. It made some one hundred proposals, which at the time of writing are under consideration.

At present then, British party finance is based upon voluntary income. This form of funding relies on the principle that parties will raise money from members and supporters and underlies the notion that political parties are voluntary organisations and that support should be provided voluntarily. In short, those who support the party's performance will fund parties. In this article, that assumption is tested with regards to parties' economic performance.

In addition to voluntary income, some state assistance is available. However, it is at a considerably lower level than in other democracies and much of it is concerned with electoral contests rather than the day to day running of parties. This is potentially problematic since, in addition to contesting regular elections at various levels, parties need to sustain political communication, recruitment and research, as well as their basic infrastructures. In short, they require a constant flow of income in order to fulfil their functions as political parties.

This article first summarises overall trends in the income of the two main political parties and compares them with patterns of party finance in other comparable democracies. Subsequently, it examines the extent to which parties can determine the levels of income required to fulfil these functions by analysing the conditions under which parties receive more or less income. 


\section{Party Funding in Britain}

Since the last war, British political parties have tended to be financed in ways common to other democracies where comprehensive state funding has not been introduced (Heidenheimer, 1970, pp. 5-9; Paltiel, 1981, pp. 143-147; Ewing, 1992, pp. 6-7). Thus, in addition to monies received from their individual membership, the Labour Party has received income from trade union affiliations and donations and the Conservatives from corporate donations. However, in recent years, these patterns have been changing. In the Conservative Party, there have been three important developments in techniques of party fundraising which indicate something of a shift away from institutional sources of finance (Fisher, 1996b, 1997, 1999). Firstly, in recent years there has been a re-emergence of personal donations to the Conservative Party to the extent that some individual donations have exceeded any made by a corporation (Pinto-Duschinsky, 1989, p. 210; Fisher, 1994a, 1997, 1999). Secondly, there has been a growth of other entrepreneurial forms of income, which are comprised largely of commercial activities such as financial services, conferences and sales. Thirdly, the proportion raised from constituency quota income has fallen considerably. This has been compounded by a continuing and projected fall in Conservative Party membership (Whiteley et al, 1994).

In the Labour Party, trade unions contribute a significant proportion of Labour's finances and help fund the party in a number of ways, including affiliation payments, grants and ad hoc donations, sponsorship of candidates and MPs, advertisements in Labour Party publications, stands at Party conferences and a wide range of payments in kind including the provision of both resources and personnel. This variety of techniques is, in part, explained by the long term institutional links between the Labour Party and affiliated trade unions. However, Labour has been successful in recent years in diversifying its fundraising, though it has been 
traditionally less successful in attracting large individual donations. Nevertheless, one of the most recent initiatives, the Labour Party Business Plan, has been largely financed by individual donations from members and supporters, or activities, such as high profile dinners, which attract money from individuals rather than institutions. In general, the Labour Party has been diversifying its income base and, whilst trade unions continue to play a very important role financially, Labour has been successful in harnessing significant income from individuals, either through donations, or through activities concerned with the Business Plan.

Parties also benefit from the limited state assistance available in Britain. The earliest example of this was the introduction of the payment of MPs in 1911. Today, parties also receive free mailing and use of public halls at elections, while the larger parties get free broadcasting. Opposition parties additionally receive 'Short' money for their work in Parliament. ${ }^{2}$ One might also add that parties have free state security provided at party conferences. This state assistance is modest in comparison with other Western democracies where the public funding of political parties is the norm (Nassmacher, 1993, p. 234). Parties in Australia, Austria, Canada, Finland, France, Germany, Israel, Italy, Norway and Sweden all receive assistance at least at national level and often at local and regional level as well (Nassmacher, 1993, pp. 241-244).

The introduction of state subsidies in many nations partly reflects concerns that political parties are facing decline in terms of strength and resources. This, in turn, makes them less able to perform the role of intermediary between the citizenry and the state (Nassmacher, 1993, p. 234; Pierre \& Svåsand, 1992, p. 2). There has also been a fear that the practice of voluntary donations can, and does, lead to corruption (Nassmacher, 1993; Pierre \& Svåsand, 1992; Gidlund, 1991). The view has been that private contributions by either individuals or groups have undesirable 
effects in the forms of preferential treatment of contributors. State funding is designed to limit or eliminate the potential for such practices.

The effects of state funding have varied. Certainly, its introduction has not succeeded in wholly eliminating corruption and loophole-seeking within the sphere of political finance. Nevertheless, comparative studies have shown there to be some common trends (Gidlund, 1991, p. 184; Nassmacher, 1989). Firstly, parties have obtained more resources, though costs have increased to a corresponding degree. Secondly, dependency by the parties on public money has been high. Thirdly, there has been a general growth in bureaucratisation and professionalisation in party organisations. Fourthly, state funding has contributed to the general trend of centralisation amongst parties. Fifthly, the importance of party memberships has declined, as has the dependence upon voluntary donations, although these have in some cases continued despite state funding (Gidlund, 1991; Drysch, 1993, p. 165; Klee, 1993, p. 193; Ciaurro, 1989, pp. 161-162). Sixth, there has been a large growth in indirect public grants to parties; an increase in party activities and a greater ability to maintain activities between elections.

In Britain, there have been strong reservations about the introduction of state funding. Firstly, it is argued that members would no longer be sought by parties and that the party system would become rigid. Certainly, the removal of the need to raise voluntary contributions has led to a loss in the incentive to recruit members in some cases (Pinto-Duschinsky, 1981, p. 8-10; Alexander, 1989, p. 17). Nevertheless, it could be argued that, in Britain where extensive state funding does not exist, party membership has been in broad and continual decline. Secondly, the fear that state funding would institutionalise present party systems, thus not permitting new party entry, has not proved correct (Gidlund, 1991, pp. 184-185; Nassmacher, 1989). Parties are often required to gain thresholds of electoral support in order to qualify for state funds and, as Nassmacher points 
out, the effect of state funding on the entry of new parties: 'is rather a question of thresholds...than of principle.' (Nassmacher, 1989, pp. 248-249). Moreover, there is little evidence that voluntary systems of party funding are any less rigid (Fisher, 2000).

Perhaps the most persuasive argument is one of principle rather than impact. It is suggested that, if a political party cannot survive financially, it is not the place of the state to intervene and maintain an organisation that cannot collect sufficient funds from its supporters (Home Affairs Committee, 1994, pp. xvii-xviii). This becomes particularly pertinent when one considers that public opinion has rarely been enthusiastic about the indispensable role of political parties (Pierre \& Svåsand, 1992, p. 12).

The report of the Neill Committee did not explicitly support an extension of public funding to political parties. However, it made a number of proposals which, if implemented, would point to an acceptance of the principle of increased public funding. Firstly, a Policy Development Fund will be established, initially cash limited to $£ 2$ million per annum, to assist parties to engage more fully on policy development. Secondly, it was proposed that the provision of 'Short' money be increased threefold. This proposal has now been approved by Parliament, although the increase agreed was a factor of 2.7 (HM Government, 1999, p. 34). Finally, the Neill Committee proposed that tax relief be provided for donations of up to $£ 500$. This would have resulted in some state funding by virtue of monies that would normally go to the Treasury. However, at this stage, this is one of the few proposals that the Government has rejected (HM Government, 1999, p. 33). If these proposals are implemented, there will, in effect, be an extension of public funding of parties. Moreover, given the Report's views that parties are fundamental to parliamentary democracy, that they should be able to function adequately and that the importance of parties goes beyond contesting elections, there is the possibility of further state aid should parties find 
themselves in financial difficulty. Given that parties face increasing campaign costs in uncertain electoral arrangements, further state aid may become a practical necessity.

\section{A Funding Cycle}

In the meantime, the absence of regular state assistance to parties has had the effect of producing a funding cycle based around the electoral cycle of British general elections (see Figures 1 and 2). ${ }^{3}$ This occurs despite the fact that both parties, although especially Labour, have a certain amount of 'routine' voluntary payments (see Figures 3 and 4 and Fisher, 2000). In the case of the Labour Party, trade union affiliations payments are regular and rarely seriously questioned by the trade unions (Fisher, 1995). In the case of the Conservative Party, whilst the level of donations does fluctuate, it still forms a relatively consistent proportion of party income. However, this funding cycle leads to two principal problems for parties. Firstly, most expenditure for British political parties is routine, ${ }^{4}$ generally constituting around $80 \%$ of both Conservative and Labour central expenditure (Fisher, 2000). Thus, in order simply to maintain themselves as viable organisations, parties require some consistent financial input. This is an important point since, if greater measures of state funding were to be introduced, they would clearly not only be spent upon advertising (which might generate negative views about state assistance ${ }^{5}$ ) but also on maintaining the parties more broadly (Fisher, 1995, p.194, 1996a, pp. 200-201).

Secondly, the notion of an electoral cycle every four to five years in British politics is something of a misnomer, at least as far as parties are concerned. Whilst parties do concentrate most resources and interest upon general elections, they also campaign on a national basis in European elections (every five years) and across large proportions of the country in the various staggered local elections. Moreover, it is worth noting that in recent 
years, local government campaigns have been fought in a far more 'national' way (Fisher, 2000). Moreover, with the advent of new parliaments and assemblies in Scotland, Wales and London, parties are now campaigning even more frequently.

[Figure 1 About Here]

[Figure 2 About Here]

[Figure 3 About Here]

[Figure 4 About Here]

The result is that, whilst voluntary funds tend to be cyclical, party expenditures are much less so. As a result, parties find themselves routinely in deficit, not necessarily by excessive campaign spending at general elections, but through simply trying to operate upon a routine basis. An examination of party expenditure as a proportion of income over time reveals this problem (see Figures 5 and 6) which is greater for the Conservatives than for Labour. This is partly due to the greater element of routine funding that Labour receives from the trade unions, but is also a reflection of trade union traditions of 'good housekeeping' (Minkin, 1991, p. 512).

[Figure 5 About Here]

[Figure 6 About Here] 


\section{Predictors of Party Income}

Levels of party income clearly fluctuate quite considerably. Preliminary visual analysis of Figures 1 to 4 provides suggestive evidence regarding the cause of such fluctuations, namely the timing of general elections. However, our understanding of the determinants of party income requires more vigorous multivariate analysis. In this section of the article, a number of aggregate indicators are used in an attempt to predict levels of income. In this way, one can assess and estimate under what conditions a party will be well or poorly funded. Moreover, one can assess to what extent parties may have any real control over these factors. Five models are employed. The models are of two types: market models and non-market models. The first three models are market-based models and are designed to test whether a market for party income exists in the same way that it could be said to do so for votes (Clarke \& Whiteley, 1990; Clarke \& Stewart, 1995; Sanders, 1992, 1996; Sanders, Ward \& Marsh, 1987). Such models work on the logic of punishment and reward. Thus, successful government performance in the economy is rewarded by continued electoral support. By way of contrast, failure results in a withdrawal of electoral support. The same logic applies to parties' voluntary income. Parties that deliver the economic 'goods' should benefit financially, whilst those that do not, should suffer a decline in their income.

Such market based models may also apply to opposition parties since Downsian theory argues that the credibility of alternative governments is also critical, particularly when ideological distance between parties is perceived to be so narrow as to render a voter unable to make a choice (Downs, 1957, pp. 41-45; Laver, 1997, pp. 99-100). Thus, just as potential electors will evaluate the alternative government to estimate its putative improved performance as compared with the incumbent, so contributors will also behave in this way. Subjective economic evaluations are also examined. This recognises the fact that subjective 
evaluations and objective states of affairs may not wholly correlate. Again, this is a marketbased model whereby subjective satisfaction should result in parties being rewarded or punished financially.

These market-based models have their roots in forms of democratic theory, which suggest that elections are a means to evaluate the performance of parties, both retrospectively and prospectively, and make choices accordingly. In these models, borrowed from studies of voting behaviour, electoral support is simply substituted with financial support. It should be noted, however, that electoral support and financial support are not identical forms of participation. Competition for votes assumes equal voting rights. Competition for funds, however, is beset by the difficulty that wealth is unevenly distributed. Indeed, some argue that inequalities in money are greater than any other inequalities of the resources that affect political life, because money can buy virtually all of the resources that are provided by citizens (Paltiel, 1981; Adamany \& Agree, 1975). Notwithstanding this caveat, if these models indicate that a market exists for party donations, then the case for more comprehensive state funding is weakened. In theory, parties would be able to enhance their level of voluntary income, either through good economic performance as incumbents, or through providing credible alternatives in opposition.

It might be argued, however, that there is an asymmetry implicit in such 'market' models; namely that, in some respects, the Conservative and Labour Parties are not competing on the same terms in such a market for donations. Certainly, corporate donations are most likely to be made to the Conservative Party (Fisher, 1994b) and, notwithstanding Labour's increasing success in this area (Fisher, 1997), that pattern broadly remains. Nevertheless, whilst the market is not identical, the principle remains. Donations by individual members to their 
parties may vary depending upon economic performance and trade unions do not confine their payments to the Labour Party as routine affiliation. Rather, they make ad hoc donations which, in theory, may reflect satisfaction or otherwise with the incumbent party's performance. In short, whilst the Conservatives might be said to have a larger potential market, since relatively few companies make donations (Fisher, 1994b), the Labour Party's non-affiliation income is clearly variable. Moreover, the willingness of individuals and organisations to take part in parties' entrepreneurial fundraising may also be said to be affected by such market-based models.

The case against treating parties as competitors for voluntary income is examined in the second group of non-market based models of party income. Under these models, which examine overall levels of disposable income and the timing of general elections, parties are expected to benefit either when contributors have more money or when elections are called. In these models, there are no parties to reward or punish and, therefore, parties have little control over their levels of voluntary income. Thus, they may be rewarded or punished, regardless of how they perform economically. If these models are successful, the case for more comprehensive state funding is strengthened in the first case because a party's supporters may be more likely to reward it financially when they have more disposable income, regardless of which party has presided over this rise. In the second model, parties cannot be rewarded or punished simply by the timing of an election. The models are described in more detail below and, overall, their use presents an attempt to evaluate the effectiveness of voluntary party income in Britain. The case for or against increased public provision is therefore evaluated empirically rather than normatively. 


\section{Model 1 - The Punishment-Reward Model}

This model utilises objective economic indicators. The basis of variable choice is twofold. First, indicators have been selected where they are commonly used to evaluate economic success (i.e. Balance of Payments, inflation). Secondly, indicators identified by donors themselves as being ones of importance are utilised (Fisher, 1994c). The model hypothesises that economic success by incumbents will be rewarded with increased party income and economic failure will be punished by a decrease.

\section{Model 2 - The Expectation-Satisfaction Model}

This model applies to opposition parties and essentially runs Model 1 in reverse. It hypothesises that when the incumbent party is experiencing economic difficulties, the level of income to opposition parties will rise. There is an expectation that an alternative government will produce more favourable economic conditions. By contrast, when incumbent parties experience good economic fortunes, levels of income to opposition parties will fall. There is satisfaction with existing government performance.

\section{Model 3 - The Evaluation Model}

This model utilises individual and corporate indicators of economic confidence. It is run separately from the previous models as the individual time series only begins in 1974. It predicts that economic evaluations will have an effect upon both incumbent and opposition income in a similar way to Models 1 and 2. Thus, increases in economic optimism and business confidence will result in financial benefits for the incumbent and any decline will result in a withdrawal of funds. Conversely, increases in public economic confidence should result in reduced income for the opposition while any decline in should result in financial benefits for that party. 
This model hypothesises that changes in disposable income will subsequently be reflected in parties' income. Variables affecting levels of disposable income include bank rates, inflation as well as an index of change in personal disposable income. It hypothesises that, when these variables improve, both parties' income will rise and vice versa. This is a trend that has been identified in the USA (Heard, 1960, p.75) and may take place under any government. It is, therefore, a non-market model.

\section{Model 5 - The Electoral Necessity Model}

This model hypothesises that levels of party income will reflect the timing of general elections and the marginality of electoral competition. Thus, party income will rise at the time of elections, especially when the electoral race is relatively close. The logic of this is that parties will require more money in a close electoral race and that contributors will feel more inclined to participate when there is greater marginality. This is a trend identified in studies of American contributions (Heard, 1960, p.75) as well as more broadly in British voter turnout (Denver, 1997).

\section{Methodology}

Data for these analyses are annual observations of the variables involved. This restriction is caused by the availability of party income data, which are produced in yearly accounts. As a result, there is no way of ascertaining whether certain periods of the year generate more income than others, for example. Where higher frequency data have been used, these have been annualised by averaging or aggregating over the year as appropriate. In view of the rather low frequency of observation, there is no need to build lags into the models as the period of one year provides a sufficient internal lag. 
The following aggregate variables are used in these analyses: Conservative central income in real terms (standardised by the RPI); Labour central income in real terms (standardised by the RPI); highest bank rate in calendar year; Balance of Payments (current account); ExportImport ratio; Growth based on GDP output; annual rate of inflation; percentage change from previous year in the maximum unemployment level; Terms of Trade index (Export Price Index as a percentage of Import Price Index); CBI Industrial Trends survey - an indicator of business confidence; prospective egocentric economic evaluations; prospective sociotropic economic evaluations; retrospective egocentric economic evaluations; retrospective sociotropic economic evaluations; percentage change from previous year in the Personal Disposable Income index; general election year (dummy variable - Yes=1 No=0); absolute levels of difference between mean party poll ratings (marginality) and pre-general election year $($ dummy variable - Yes $=1 \mathrm{No}=0){ }^{6}$

The use of these time-series data presents three methodological issues that need to be addressed. First, before conventional regression analyses are undertaken, one needs to establish whether the variables are stationary. The use of nonstationary variables, that is those that do not fluctuate around a constant mean, can produce spurious findings in regression analyses. This is because in time-series analyses, theoretically unrelated variables can appear to be related because they grow (or decline) in a similar way (Clarke, Stewart \& Whiteley, 1997, p.148). A common procedure for testing nonstationarity is the Dickey-Fuller test. The most common method of performing this test is as follows:

$\Delta X_{t}=\alpha+\beta_{1} X_{t-1}+\epsilon_{t}($ Eq.1) 
Where $\Delta X_{t}$ is the first difference of variable $X$ at time $t ; \alpha$ is a constant; $\beta_{1}$ is a regression coefficient; $X_{t-1}$ is the level of variable $X$ at time $t-1 ; \epsilon_{t}$ is the error term. The $t$ value of $\beta_{1}$ is nonstandard but takes an appropriate value in tables of the Dickey-Fuller test. The results of the Dickey-Fuller tests on all time-series variables are shown in Table 1. These illustrate that the variables can be considered to be stationary and therefore suitable for use in these regression analyses.

[Table 1 About Here]

The second problem is that analyses with time-series data can suffer from autocorrelation - a situation where the best predictor of the level of the dependent variable is that which occurs at the previous observation. To counter this problem all models include a lagged endogenous variable and the existence of any evidence of autocorrelation is examined by the use of the Durbin-Watson test.

The final problem is that, for the market-based models, it is necessary to distinguish between periods of incumbency and opposition. If these data were cross-sectional, a common procedure to differentiate the effects of opposition and incumbency would be to simply divide the data by those criteria and compare regressions. However, the use of time-series presents a problem since splitting the data entails interrupting the time-series. In addition, in a time series such as this, with a relatively small number of observations, splitting the data can create an unacceptable reduction in the degrees of freedom. One solution to this problem is to employ an intercept dummy variable to denote incumbency or opposition, together with a dummy interaction variable. This is produced by multiplying the dummy variable by the relevant independent variable and captures differences in the slope (Gujarati, 1992, pp 260- 
78). By using these techniques, problems of interrupted time-series are avoided. ${ }^{7}$ Thus, such models in these analyses take the following general form:

$Y_{t}=\alpha+\beta_{1} Y_{t-1}+\beta_{2} D_{t}+\beta_{3} X_{t}+\beta_{4}\left(D_{t} * X_{t}\right)+\epsilon_{t}$

Where: $\alpha$ is a constant; $Y_{t}$ is the dependent variable; $Y_{t-1}$ is the dependent variable lagged by one observation (to alleviate autocorrelation); $D_{t}$ is the dummy intercept term ( $1=$ Incumbent and $0=$ Opposition); $X_{t}$ is an independent variable; $\left(D_{t}^{*} X_{t}\right)$ is the interaction variable of $X_{t}$ multiplied by $D_{t} ; \epsilon_{t}$ is the error term; $\beta_{1-4}$ are regression coefficients.

There is also one further methodological issue that arises from the particular kinds of aggregate data employed here. The analysis of objective economic data, particularly where observations are relatively infrequent (as they are here), can present problems of collinearity. That is a situation whereby independent variables are themselves strongly correlated. The existence of collinearity and multi-collinearity can lead to spurious regressions. As a means of avoiding such problems, the objective economic indicators analysed here were entered into a factor analysis. Before this was done however, there was a need to ensure that all variables were directionally similar - that is to say that a rise in the value of an individual variable generally indicated economic success, whilst a fall indicated under-performance. This presented a problem in terms of the three variables where a decline might be viewed as beneficial - bank rates, inflation and unemployment. In order to solve this problem, these three variables were indexed so that a rise in the level of those variables now indicated economic success. 
Table 2 shows that the factor analysis produced three clear components. Factor 1 may be said to represent the domestic business economy. The component correlates most strongly with the bank rate, inflation and the terms of trade index. Factor 2 represents the domestic individual economy. It correlates most strongly with unemployment, inflation and growth. Factor 3 represents the international economy. This correlates most strongly with the balance of payments and the ratio of exports to imports. Factor scores from this analysis were then produced, tested for stationarity and used in subsequent regressions.

[Table 2 About Here]

For all the tables that follow, Ordinary Least Squares (OLS) is used. All models are run using party central income as the dependent variable. Total income, rather than total donations is used since increases in income are not necessarily derived from direct voluntary payments, but also from such things as parties' entrepreneurial activities. Such activities would be likely to be affected by the independent variables used here, but would not be classified as donations. All models also include an endogenous variable lagged by one year to alleviate the problem of autocorrelation.

\section{Results}

\section{The Punishment-Reward Model}

This model employs interaction terms as illustrated in Equation 2. The results relevant to this model - the incumbent years - are reported in Table 3. In terms of Conservative income, the objective economy appears to have very little impact, Only one parameter - the international economy factor - is statistically significant. However, that parameter is negatively signed. This suggests that the worse the British international economy performs under Conservative 
administrations, the greater the income to the Conservative Party. This is a counter-intuitive finding. As far as the other key variables are concerned, whilst the Domestic Individual Economy is correctly signed, the Domestic Business Economy is not, though, of course, neither attain statistical significance. Finally, the model fit is very poor. Under Labour governments, it is again only the Domestic Individual Economy that is correctly signed. However, as with the other two economic factors, it is not statistically significant. Overall, it would seem that the state of the economy has little discernible impact upon the financial success or otherwise of incumbent parties.

[Table 3 About Here]

\section{The Expectation-Satisfaction Model}

The same form of model used for the Punishment-Reward models for incumbents is then run for periods of opposition. The results are reported in Table 4. In these models, the expectation is that the economic factors will be negatively signed - suggesting that economic underperformance will benefit opposition parties. This is the case for the model examining Labour income whilst in opposition. None of these parameters are, however, statistically significant. For the Conservative Party, only the International Economy Factor is correctly signed. Both domestic factors are positively signed, suggesting that improvements in the domestic economy under Labour governments benefit the Conservative Party financially - a counter intuitive finding. Again however, none of these parameters attain statistical significance. Thus, as for incumbent parties, the state of the economy would appear to have little impact upon the financial success of the opposition party.

[Table 4 About Here] 


\section{The Evaluation Model}

Doubts about the existence of a functioning market for party income continue when the results of the Evaluation model are examined in Table 5. Interaction techniques are again used. However, only the results of Conservative incumbent and Labour opposition years are reported as the individual evaluation time series only begins in 1974. The analyses for this model were run with all types of personal economic evaluations (prospective egocentric, prospective sociotropic, retrospective egocentric and retrospective sociotropic) as well as with various scales built from these indicators (prospective, retrospective, egocentric, sociotropic, all evaluations and a factor score from all four indicators). Only the results from the prospective sociotropic models are reported here as these produced the best model fit.

For the Conservative Party, the individual economic evaluation is correctly signed and is statistically significant. Thus, when prospective sociotropic evaluations under Conservative governments improve, this is accompanied by a rise in Conservative income. However, what is also interesting is that a decline in the CBI Industrial Trends Survey is also associated with a rise in Conservative income. Although this parameter fails to attain statistical significance, the fact that it is not positively signed, or significant, questions one of the long-held reasons given for donations to the Conservative Party - that it is 'the party of business' (Fisher, 1994b, pp 692-5). The CBI Industrial Trends Survey is a measure of business confidence and one would expect that rises in this indicator under Conservative administrations would be rewarded. This is not the case.

For Labour, the CBI Survey is not included in the analysis reported here. This is because there is a far less likely link between business confidence and party income. ${ }^{8}$ Individual 
economic evaluations are incorrectly signed - suggesting that increases in prospective sociotropic evaluations under Conservative governments benefit Labour income. The parameter is not however, statistically significant.

Overall, it would appear that market-based models have very limited success in predicting levels of party income. Most results are either nonsignificant or counter-intuitive. Only in one area - individual economic evaluations - does there appear to be an effect consistent with the hypotheses. Thus, in economic terms at least, parties would appear to have little control over their finances. Their income rises and falls almost regardless of how well or how badly they perform.

[Table 5 About Here]

\section{The Disposable Income Model}

The Disposable Income model offers an alternative hypothesis. It rejects the notion of a market and predicts that party income will be a function of greater overall wealth. Crucially, it is not a matter of concern which party has presided over rises and falls in these indicators. The results are reported in Table 6. This model appears to suggest that, for both parties, lower rates of inflation tend to benefit that party's coffers. No other disposable income parameters have a statistically significant impact upon Conservative income, though is it worth noting that reductions in the rise in personal disposable income do appear to benefit the Conservatives, although of course this is nonsignificant. For Labour, not only does lower inflation benefit the party, but higher bank rates do as well. This appears to be counterintuitive although one might argue that savers would benefit from higher rates, and so this group may then contribute more funds to the party. Notwithstanding that debate, it is clear 
that lower inflation appears to benefit both parties' incomes. Crucially however, this is the case regardless of which party has presided over periods of lower inflation.

[Table 6 About Here]

\section{The Electoral Necessity Model}

The Electoral Necessity model seeks to measure what Figures 1 to 4 appear to suggest, namely that it is the timing of British general elections which most affects parties' income. This hypothesis appears to be broadly borne out. For both parties, general election years have a strong and statistically significant effect. The importance of the general election cycle is further emphasised by the fact that pre-election years also have a positive impact, reflecting the fact that parties attempt to build up income in the expectation of general elections. Given that the United Kingdom has variable dates for its general elections, this partially reflects the uncertainty that at least opposition parties experience in trying to predict their timing.

For the Conservatives, a larger margin between the poll ratings is also a factor affecting party income. This may be seen a being counter-intuitive, since we might expect greater marginality to increase income rather than vice versa. On the other hand, this may illustrate a bandwagon effect, which occurs when election victory is very likely. Certainly, this has been a trend identified in the past in the USA (Heard, 1960, p.69). This variable is also positively signed for Labour, though is not statistically significant. Finally, it is worth noting that, for both parties, the fit for this model is much more impressive than that for any of the other models analysed here - suggesting that the electoral necessity model is the best for explaining party income. 
The results of these empirical tests suggest that it is electoral necessity that promotes variation of party income rather than it being a reflection of economic performance. Parties are better funded when there is low inflation and in the run up to general elections. The performance of parties (at least in economic terms) does not appear to affect their income to any significant degree. As a consequence, it may be argued that parties will have less control over variations in their income. No matter how well a party performs in government or opposition, their voluntary income is not affected. What matters, is when general elections are held.

The implications arising from this are clear. Whilst funding appears to reflect the general election cycle, the needs of parties do not. Parties must function at both routine and campaigning levels throughout this cycle, yet income largely remains a function of one electoral cycle. This has two principal effects. For the Conservatives, it has led to continual overspending. Labour has resisted this trend, but for both parties the implication is that resources cannot be devoted to all functions to the degree that might be deemed desirable. Even in the area of campaigning, parties can clearly dedicate only a limited proportion of their resources to second-order (non-general) elections. Since levels of campaigning are positively correlated with turnout (Denver \& Hands, 1997, 1998), this has potentially wider implications - particularly when turnout in second-order elections is becoming a source of concern. Beyond the importance of campaigning, income based upon the general election cycle leads to problems of parties fulfilling their other functions - two of which are political education and communication, which again are likely to be variables with the potential to affect electoral turnout. 
Thus, if parties have little control over the levels of their voluntary income, at least in terms of performance, and if parties are possibly underfunded in terms of fulfilling their functions successfully, the case for enhanced levels of public provision become a little stronger. However, the Neill Committee did not explicitly support state funding. Beyond the measures outlined earlier in this article, the committee took the view that the time for comprehensive state funding had not yet arrived. The Report argued that the proposed national spending limits would curb parties' need for ever-increasing resources and also cast doubt upon the arguments that parties were underfunded (Committee on Standards in Public Life, 1998, p.92). There is merit in this view, but it is based on the assumption that campaigning is excessive and requires curbing. This is a debatable point since, by definition, campaigning raises the electorate's political awareness and possibly the level of political education. At a time when there are concerns over political engagement, it might seem odd to curb this form of political communication. Moreover, if income is largely driven by the electoral cycle, it is unlikely that parties will be able to stockpile resources for non-election years, since that would entail donors contributing in the knowledge that election expenditure (which has stimulated contributions) is to be limited. Such limitations would logically be a disincentive to make a contribution.

Yet, for all that, the Neill Report does go further than any previous enquiry in political finance and critically stands more chance of being implemented. Not only does it propose a limited increase in state funding, it also explicitly recognises that parties are essential to parliamentary democracy and that all of their functions require adequate financing. Moreover, the Report recommends that in order to guarantee fairness in referendum campaigns are fair, registered campaigns may apply for core public funding (Committee on Standards in Public Life, 
1998, p.164). The implication here is that the market is insufficient to provide an even political contest - a principle that could theoretically be applied to elections. In short, the Report does not rule out comprehensive state funding in the future.

\section{Conclusions}

Underlying the notion of the voluntary basis of party funding is the principle that funds are provided voluntarily by supporters in response to continuing support for the party. Parties therefore succeed or fail financially depending upon whether they retain support. Models 1,2 and 3 (Punishment-Reward, Expectation-Satisfaction and Evaluation) test this assumption. If a market for party income exists in the same way that it could be said to do so for votes, then the empirical case for more comprehensive state funding would be weakened. Parties would, in theory, be able to enhance their level of income, either through good economic performance as incumbents, or by providing credible alternatives in opposition. The case against treating parties as competitors for income is examined by means of Models 4 and 5 which test the extent to which a party's income is dependent upon levels of personal disposable income under any administration and the timing of the principal election. If these models provide strong explanations for variation in party income, the empirical case for state funding is strengthened since parties effectively have little control over their finances in terms of their performance.

All the models presented here could be employed to evaluate the effectiveness of any system of party finance that relies to a significant extent upon voluntary income. In the case of Britain, it is clear that electoral considerations, rather that economic performance, are the best predictor of party income and that, empirically at least, the case for more comprehensive public funding is stronger. In short, the assumption that parties may have control over their 
income by virtue of their performance is seriously undermined. Thus the basis of voluntary income as an effective means of distributing funds to competing parties is seriously questioned. Parties require funds to operate on a constant basis, yet often struggle for resources and cannot entirely predict their own income, since they are not necessarily rewarded for success or punished for failure. It is difficult then to sustain any argument that parties must compete for income. As such, if we accept the case that healthy political parties are an important aspect of democratic life, then the case for providing more comprehensive public assistance becomes at least, a little stronger. 


\section{References}

Adamany, D.W., Agree, G.E. (1975), Political Money, Baltimore: John Hopkins Press.

Alexander, H. (1989), 'Money and politics: rethinking a conceptual framework', in Alexander, H. (ed), Comparative Political Finance in the 1980s, Cambridge: Cambridge University Press.

Annual Abstract of Statistics, London HMSO.

Butler, D \& Butler, G. (1994), British Political Facts 1900-1994, London: MacMillan.

Ciaurro, G.F. (1989), 'Public financing of parties in Italy', in Alexander, H. (ed), Comparative Political Finance in the 1980s, Cambridge: Cambridge University Press.

Clarke, H. \& Whiteley P. (1990), 'Perceptions of macroeconomic performance, government support and Conservative party strategy in Britain 1983-87,' European Journal of Political Research, 18 (1) January.

Clarke, H. \& Stewart M. (1995), 'Economic Evaluations and Election Outcomes: An Analysis of Alternative Forecasting Models', in Broughton, D., Farrell, D.M., Denver, D. \& Rallings, C. (eds) British Elections \& Parties Yearbook 1994, London: Frank Cass.

Clarke, H., Stewart, M. \& Whiteley, P. (1997), 'Error Correction Models of Party Support: The Case of New Labour', in Pattie, C., Denver, D., Fisher, J. \& Ludlam, S. (eds) British Elections \& Parties Review Volume 7, London: Frank Cass.

Committee on Standards in Public Life (1998), The Funding of Political Parties in the United Kingdom, London: The Stationary Office. Cm 4057-1.

Denver, D. (1997), 'The Results: How Britain Voted' in Geddes, A. \& Tonge J. (eds), Labour's Landslide, Manchester: Manchester University Press.

Denver, D. \& Hands, G., (1997), Modern Constituency Electioneering, London: Frank Cass.

Denver, D. \& Hands, G. (1998), 'Constituency Campaigning in the 1997 General Election: Party Effort and Electoral Effort' in Crewe. I.,, Gossalk, B. \& Bartle, J. (eds), Political Communications: Why Labour Won the General Election of 1997, London: Frank Cass.

Downs, A. (1957), An Economic Theory of Democracy, New York: Harper and Row.

Drysch, T. (1993), 'The New French System of Political Finance', in Gunlicks, A.B. (ed), Campaign and Party Finance in North America and Western Europe, Boulder: Westview Press.

Economic Trends, London: HMSO.

Ewing, K. (1992), Money, Politics \& Law, Oxford: Clarendon Press. 
Fisher, J. (1992), Trade Union Political Funds and the Labour Party', in Norris, P., Crewe, I., Denver, D. \& Broughton, D. (eds) British Elections \& Parties Yearbook 1992, Hemel Hempstead: Harvester Wheatsheaf.

Fisher, J. (1994a), Political Donations to the Conservative Party', Parliamentary Affairs, 47 (1) January.

Fisher, J. (1994b), 'Why Do Companies Make Donations To Political Parties?' Political Studies, 42 (4) December.

Fisher, J (1994c), 'Rationality and Institutional Political Donations', Paper Presented to the European Consortium for Political Research, Madrid.

Fisher, J. (1995), 'The Institutional Funding of British Political Parties', in Broughton D., Farrell, D., Denver, D. \& Rallings, C. (eds), British Elections \& Parties Yearbook 1994, London: Frank Cass.

Fisher, J. (1996a), British Political Parties, Hemel Hempstead: Prentice Hall.

Fisher, J. (1996b), 'Party Finance', in P. Norton (ed), The Conservative Party, Hemel Hempstead: Prentice Hall.

Fisher, J. (1997), 'Donations to Political Parties', Parliamentary Affairs , 50 (2) April.

Fisher, J. (2000), 'Financing Party Politics in Britain', in Malamud, C. \& Posado-Carbó, E. (eds), Financing Party Politics in Europe and Latin America (London: Institute of Latin American Studies - forthcoming).

Gidlund, G. (1991), 'The nature of public financing in Nordic states', in Wiberg, M. (ed), The Public Purse and Political Parties, Helsinki: Finnish Political Science Association.

Gujarati, D. (1992), Essentials of Econometrics, Singapore: McGraw Hill.

Heard, A. (1960), The Costs of Democracy, Chapel Hill, NC: University of North Carolina Press

Heidenheimer, A.J. (1970), 'Major Modes of Raising Spending and Controlling Public Funds During and Between Election Campaigns', in Heidenheimer, A.J. (ed), Comparative Political Finance, Massachusetts: Heath.

Home Affairs Select Committee (1994), Funding of Political Parties, London: HMSO.

HM Government (1999), The Funding of Political Parties in the United Kingdom: The Government's proposals for legislation in response to the Fifth Report of the Committee on Standards in Public Life, London: The Stationary Office. Cm 4413

Klee, G (1993), 'Financing Parties and Elections in Small European Democracies: Austria and Sweden', in Gunlicks, A.B. (ed), Campaign and Party Finance in North America and Western Europe, Boulder: Westview Press. 
Laver, M. (1997), Private Desires, Political Action. London: Sage.

Minkin, L. (1991), The Contentious Alliance, Edinburgh: Edinburgh University Press.

Nassmacher, K.H. (1989), 'Structure and impact of public subsidies to political parties in Europe: the examples of Austria, Italy, Sweden and West Germany', in Alexander, H. (ed), Comparative Political Finance in the 1980s, Cambridge: Cambridge University Press.

Nassmacher, K.H. (1993), 'Comparing Party and Campaign Finance in Western Democracies', in Gunlicks, A.B. (ed), Campaign and Party Finance in North America and Western Europe, Boulder: Westview Press.

Paltiel, K.Z. (1981), 'Campaign Finance: Contrasting Practices and Reforms', in Butler, D., Penniman, H.R. \& Ranney, A. (eds), Democracy at the Polls, Washington: American Enterprise Institute.

Pierre, J. and Svåsand, L. (1992), 'The Parties and the State: Money, Members and Managers', Paper Presented to the European Consortium for Political Research, Limerick.

Pinto-Duschinsky, M. (1981), British Political Finance 1830-1980, London: American Enterprise Institute.

Pinto-Duschinsky, M. (1985), 'Trends in British Political Funding 1979-1983', Parliamentary Affairs, 38 (3) July.

Pinto-Duschinsky, M. (1989), 'Trends in British Party Funding 1983-1987', Parliamentary Affairs, 42 (2) April.

Sanders, D. (1992), 'Why the Conservative Party Won-Again', in King A., Crewe, I., Denver, D., Newton, K, Norton, P., Sanders, D. \& Seyd, P., Britain at the Polls 1992, Chatham: Chatham House.

Sanders, D. (1996), 'Economic Performance, Management Competence and the Outcome of the Next General Election', Political Studies, 44 (2) June.

Sanders, D., Ward, H. \& Marsh, D., (1987), 'Government popularity and the Falklands war: a reassessment', British Journal of Political Science, 17 (3) July.

Webb, P. (1992), 'The United Kingdom', in Katz, R.S., \& Mair, P. (eds), Party Organisations, London: Sage.

Whiteley, P., Seyd, P., \& Richardson, J. (1994), True Blues, Oxford: Clarendon Press. 
Figure 1

Conservative Central Income (Real Terms) 1959-94

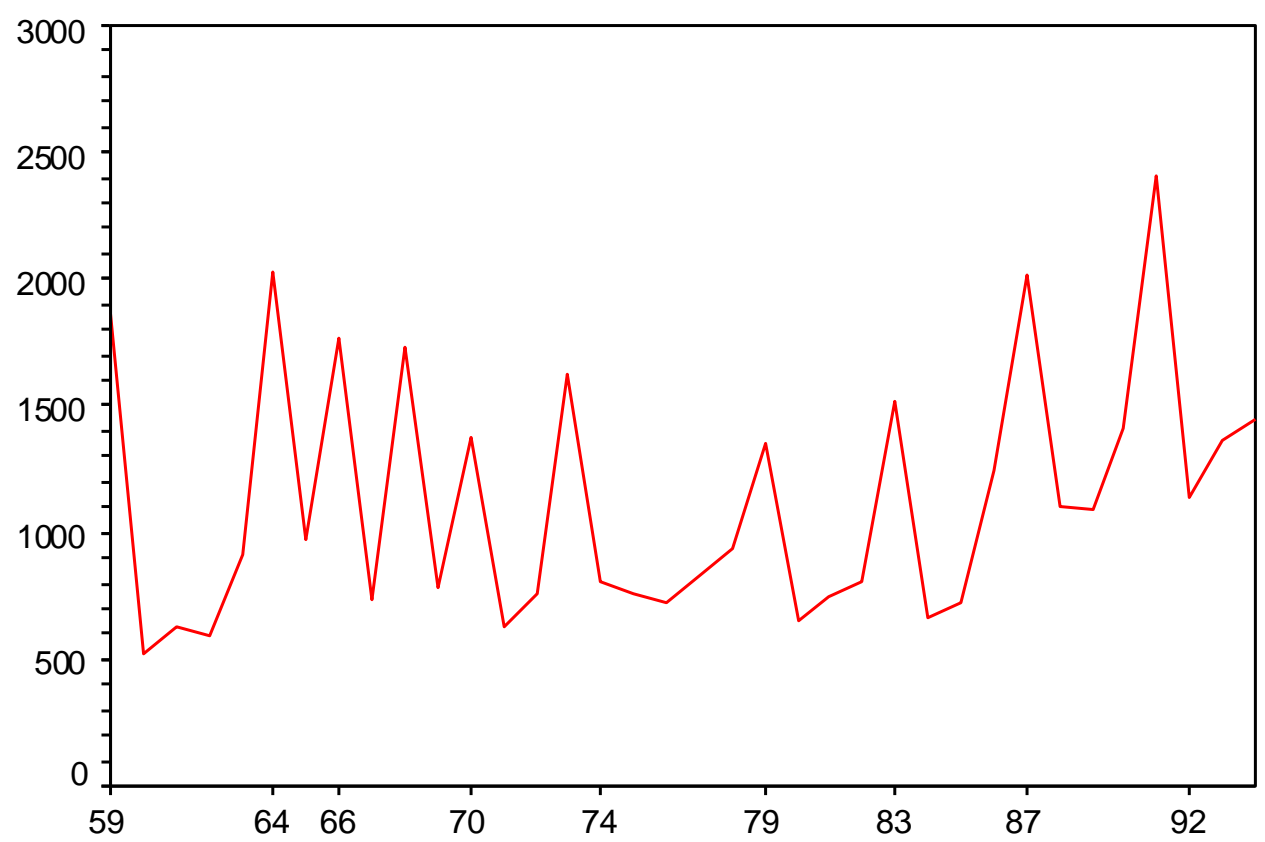

Year (General Election) 
Figure 2

Labour Party Central Income (Real Terms) 1959-94

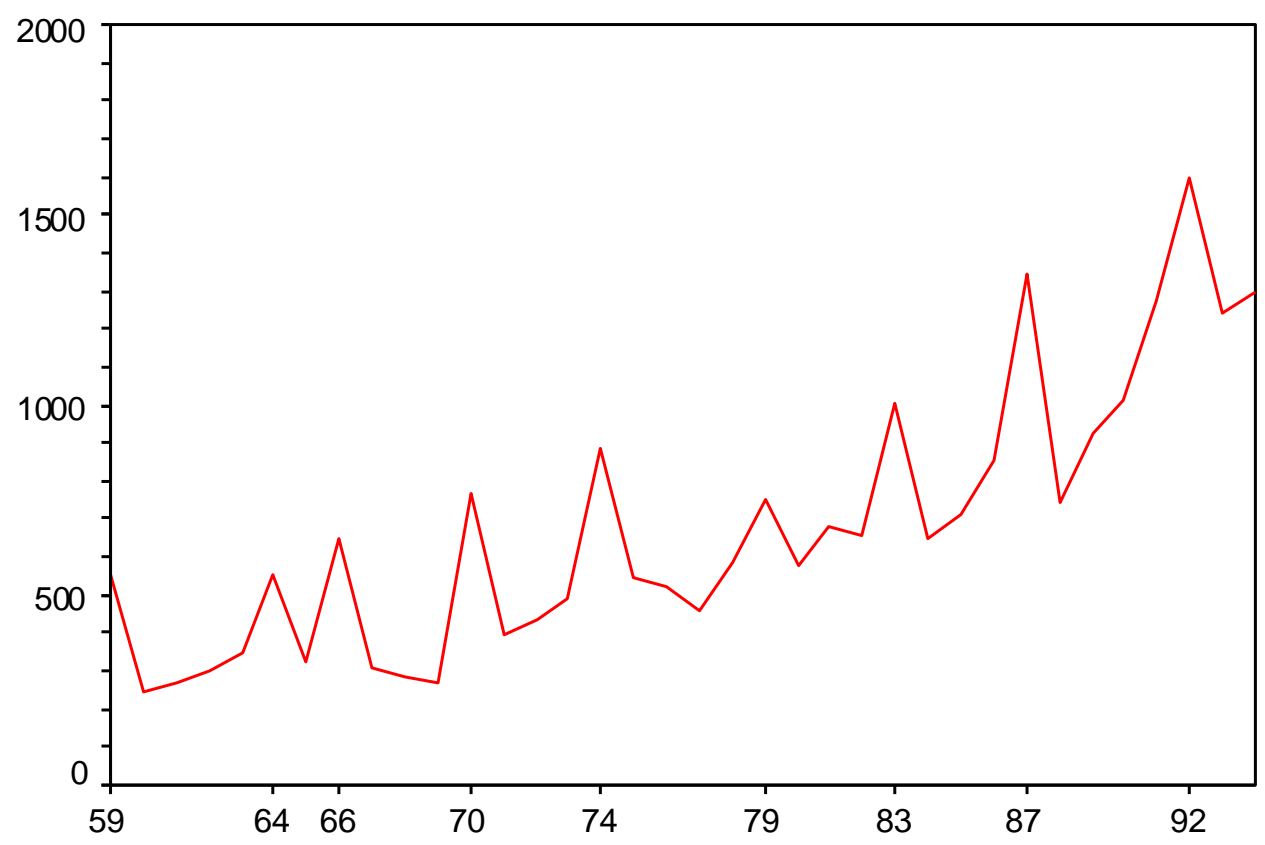

Year (General Election) 
Figure 3

Conservative Party Donations (Real Terms) 1959-94

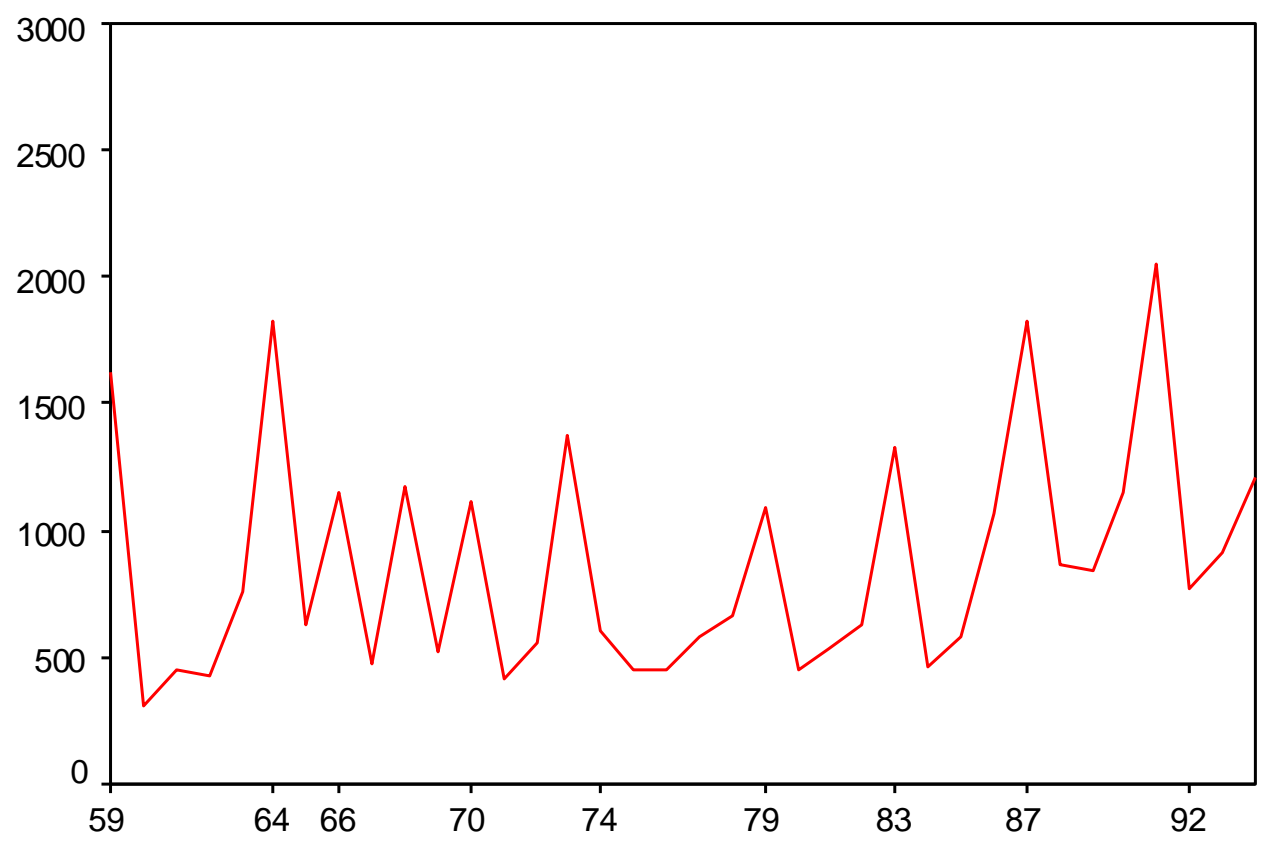

Year (General Election) 
Figure 4

Non-Trade Union Affiliation Income to the Labour Party (\%) 1959-94

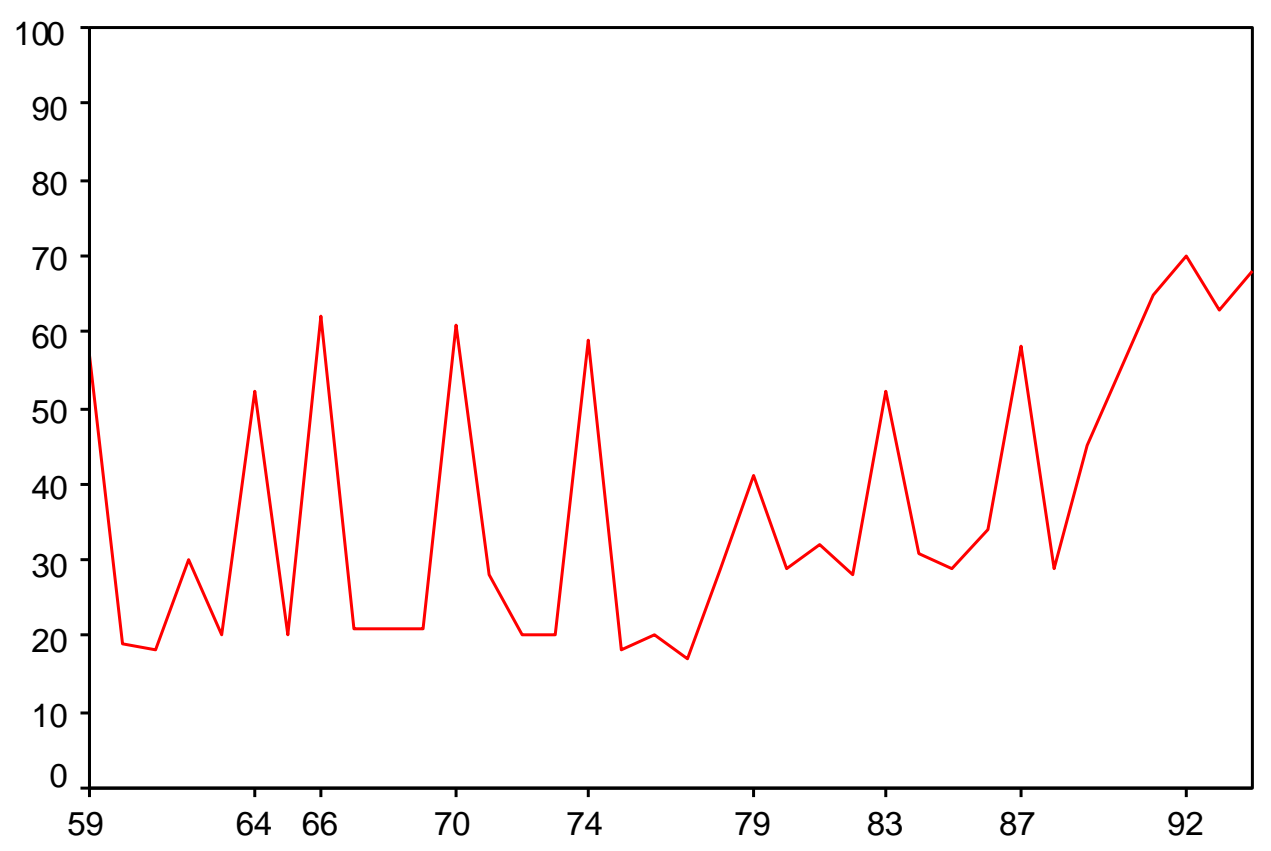

Year (General Election) 
Figure 5

Conservative Party

Central Expenditure as a Percentage of Central Income 1959-94

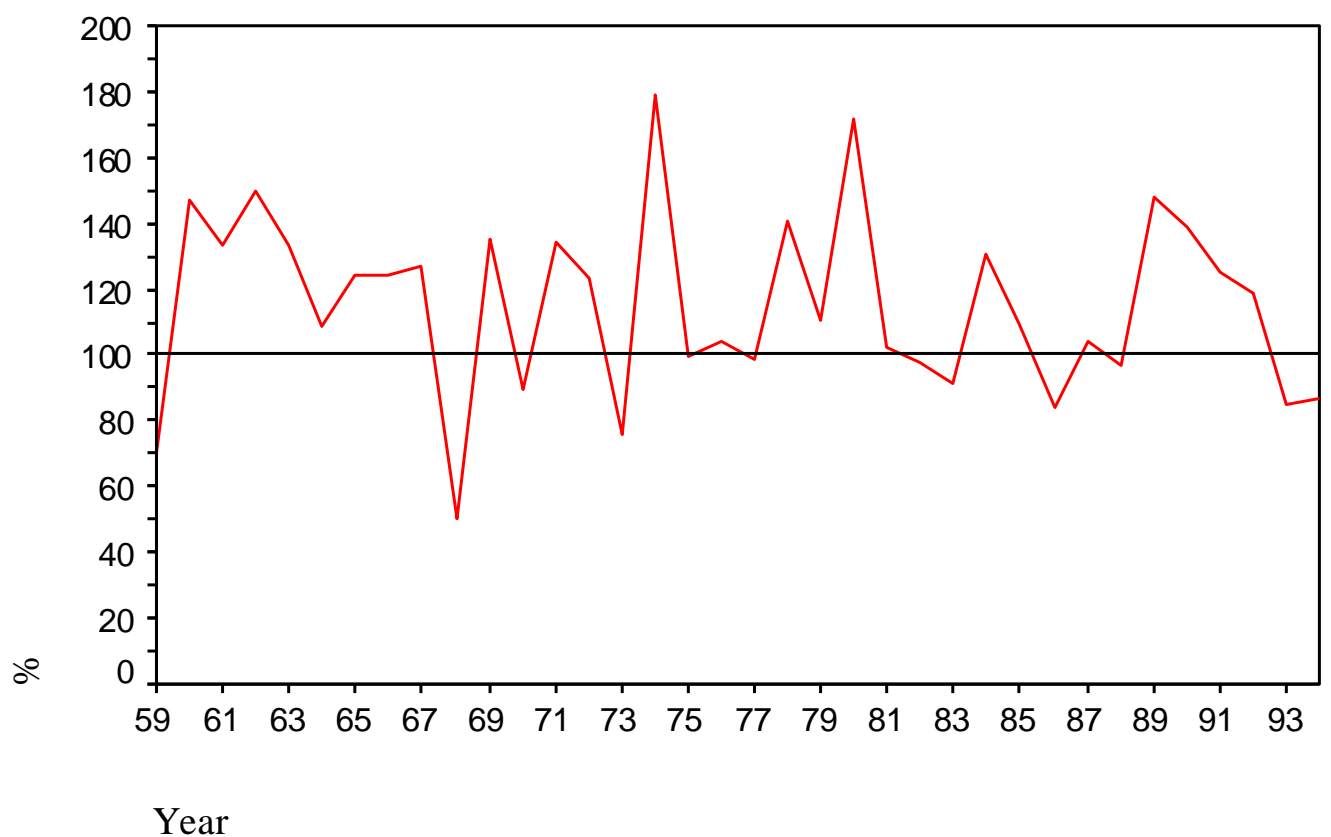


Figure 6

Labour Party

Central Expenditure as a Percentage of Central Income 1959-94

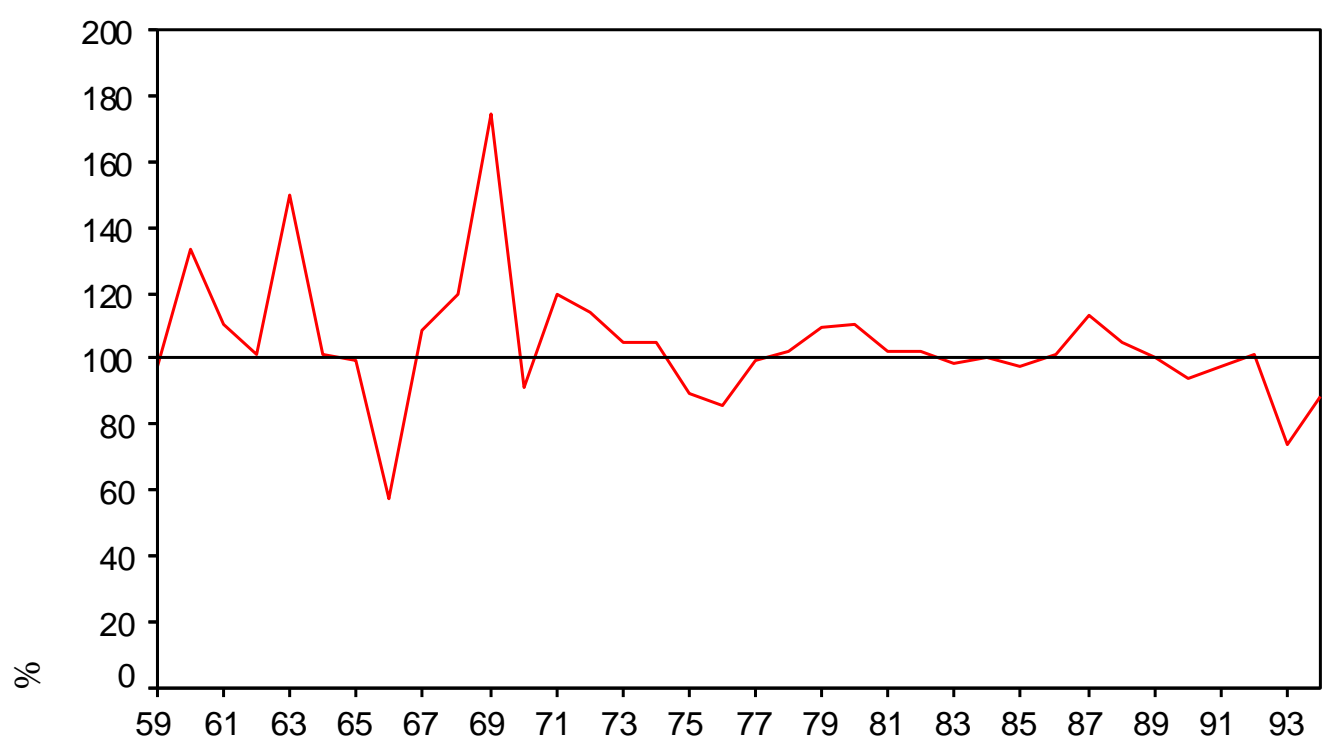

Year 
Table 1

Dickey-Fuller Tests

Variable

$\begin{array}{rrr}t & \begin{array}{r}\text { Level of } \\ \text { value }\end{array} & \begin{array}{r}\text { Critical } \\ \text { Value }\end{array} \\ & \text { ce } & \\ -1.938 & * & -1.61 \\ -1.758 & * & -1.61 \\ -4.435 & * * * & -2.78 \\ -6.122 & * * * & -2.78 \\ -2.557 & * * & -2.00 \\ -4.352 & * * * & -2.88 \\ -2.113 & * * & -2.06 \\ -2.021 & * * & -2.00 \\ -3.377 & * * * & -2.78 \\ -5.598 & * * * & -2.88 \\ -4.586 & * * * & -2.88 \\ -3.359 & * * * & -3.08 \\ -2.069 & * * & -2.00\end{array}$

$\begin{array}{ll}* * * & \text { significant at } 0.01 \text { level } \\ * * & \text { significant at } 0.05 \text { level } \\ * & \text { significant at } 0.1 \text { level }\end{array}$ 
Table 2

Factor Analysis of Objective Economic Indicators

\begin{tabular}{lrrr} 
& \multicolumn{3}{c}{ Component } \\
& \multicolumn{1}{c}{1} & \multicolumn{1}{c}{2} & 3 \\
\hline Bank Rate & 0.844 & & \\
Balance of Payments & & & 0.941 \\
Export-Import Ratio & & & 0.845 \\
Growth & & 0.867 & \\
Inflation & 0.755 & 0.443 & \\
Maximum & & 0.833 & \\
Unemployment & & & \\
Terms of Trade & 0.858 & & \\
\hline $\begin{array}{l}\text { Eigenvalue } \\
\text { \% of Variance }\end{array}$ & 2.193 & 1.759 & 1.743 \\
Explained & 31.3 & 25.1 & 24.9 \\
Dickey-Fuller Sig. & & & \\
n=35 & $*$ & $* *$ & $*$ \\
& & &
\end{tabular}

Note: Table contains varimax factor loadings which exceed 0.40 in value. Principal Components Analysis used with factors extracted with an eigenvalue $>1$.

\footnotetext{
*** $\quad$ significant at 0.01 level

** $\quad$ significant at 0.05 level

* $\quad$ significant at 0.1 level
} 
Table 3

\section{Punishment-Reward Model}

\begin{tabular}{|c|c|c|c|c|c|c|}
\hline \multirow[t]{2}{*}{$\begin{array}{l}\text { Period } \\
\text { Dependent Variable }\end{array}$} & \multicolumn{3}{|c|}{$\begin{array}{l}\text { Conservative Incumbent } \\
\text { Conservative Income }\end{array}$} & \multicolumn{3}{|c|}{$\begin{array}{l}\text { Labour Incumbent } \\
\text { Labour Income }\end{array}$} \\
\hline & $b$ & $t$ & $p$ & $b$ & $t$ & $p$ \\
\hline Constant & 1333.173 & 4.165 & $* * *$ & 351.872 & 2.639 & $* * *$ \\
\hline $\begin{array}{l}\text { Conservative/Labour } \\
\text { Income }_{\mathrm{t}-1}\end{array}$ & -0.216 & -1.098 & & 0.574 & 3.401 & $* * *$ \\
\hline Incumbency Dummy & 42.557 & 0.207 & & -153.365 & -1.311 & \\
\hline $\begin{array}{l}\text { Domestic Business } \\
\text { Economy }\end{array}$ & -108.611 & -0.227 & & -61.859 & -0.926 & \\
\hline $\begin{array}{l}\text { Domestic } \\
\text { Economy }\end{array}$ & 81.339 & 0.170 & & 11.081 & 0.107 & \\
\hline International Economy & -172.075 & -0.359 & $*$ & -76.185 & -0.469 & \\
\hline $\begin{array}{l}\text { Adjusted } \mathrm{R}^{2} \\
\text { Durbin-Watson } \\
\mathrm{n}=35\end{array}$ & $\begin{array}{l}0.010 \\
1.984\end{array}$ & & & $\begin{array}{l}0.565 \\
2.338\end{array}$ & & \\
\hline
\end{tabular}

\footnotetext{
*** significant at 0.01 level

** $\quad$ significant at 0.05 level

* $\quad$ significant at 0.1 level
} 
Table 4

\section{Expectation-Satisfaction Model}

\begin{tabular}{|c|c|c|c|c|c|c|}
\hline $\begin{array}{l}\text { Period } \\
\text { Dependent Variable }\end{array}$ & $\begin{array}{c}\text { Conservativ } \\
\text { Conservativ } \\
b\end{array}$ & $\begin{array}{l}\text { Opposit } \\
\text { Income } \\
t\end{array}$ & tion & $\begin{array}{l}\text { Labour Opp } \\
\text { Labour Ince } \\
\quad b\end{array}$ & $\begin{array}{l}\text { osition } \\
\text { me } \\
\qquad t\end{array}$ & $p$ \\
\hline Constant & 1375.730 & 5.910 & $* * *$ & 198.507 & 1.585 & \\
\hline $\begin{array}{l}\text { Conservative/Labour } \\
\text { Income }_{\mathrm{t}-1}\end{array}$ & -0.216 & -1.098 & & .574 & 3.401 & $* * *$ \\
\hline Opposition Dummy & -42.557 & -0.207 & & 153.365 & 1.311 & \\
\hline $\begin{array}{l}\text { Domestic Business } \\
\text { Economy }\end{array}$ & 176.787 & 1.476 & & -68.312 & -0.955 & \\
\hline $\begin{array}{l}\text { Domestic Individual } \\
\text { Economy }\end{array}$ & 15.404 & 0.082 & & -23.349 & -0.445 & \\
\hline International Economy & -66.350 & -0.216 & & -43.959 & -0.795 & \\
\hline $\begin{array}{l}\text { Adjusted } \mathrm{R}^{2} \\
\text { Durbin-Watson } \\
\mathrm{n}=35\end{array}$ & $\begin{array}{l}0.010 \\
1.984\end{array}$ & & & $\begin{array}{l}0.565 \\
2.338\end{array}$ & & \\
\hline $\begin{array}{ll}* * * & \text { significant at } 0.01 \text { level } \\
* * & \text { significant at } 0.05 \text { level } \\
* & \text { significant at } 0.1 \text { level }\end{array}$ & & & & & & \\
\hline
\end{tabular}


Table 5

\section{Evaluation Model}

\begin{tabular}{|c|c|c|c|c|c|c|}
\hline $\begin{array}{l}\text { Period } \\
\text { Dependent Variable }\end{array}$ & $\begin{array}{l}\text { Conservati } \\
\text { Conservati }\end{array}$ & $\begin{array}{l}\text { Incumb } \\
\text { Income }\end{array}$ & & $\begin{array}{l}\text { Labour Op } \\
\text { Labour Inc }\end{array}$ & $\begin{array}{l}\text { sition } \\
\text { he }\end{array}$ & \\
\hline & $b$ & $t$ & $p$ & $b$ & $t$ & $p$ \\
\hline Constant & 833.076 & 2.573 & ** & 333.089 & 1.826 & $*$ \\
\hline $\begin{array}{l}\text { Conservative/Labour } \\
\text { Income }\end{array}$ & 0.023 & 0.101 & & 0.462 & 2.131 & $* *$ \\
\hline $\begin{array}{l}\text { Incumbency/Opposition } \\
\text { Dummy }\end{array}$ & 627.597 & 1.937 & $*$ & 275.668 & 1.349 & \\
\hline CBI Industrial Trends & -4.858 & -0.650 & & $X$ & $\mathrm{X}$ & \\
\hline Prospective Sociotropic & 25.623 & 1.826 & $*$ & 6.747 & 1.075 & \\
\hline Adjusted $\mathrm{R}^{2}$ & 0.073 & & & 0.334 & & \\
\hline $\begin{array}{l}\text { Durbin-Watson } \\
\mathrm{n}=21\end{array}$ & 1.552 & & & 2.014 & & \\
\hline
\end{tabular}

\footnotetext{
X Variable Not Included in Model

*** significant at 0.01 level

** $\quad$ significant at 0.05 level

* $\quad$ significant at 0.1 level
} 
Table 6

The Disposable Income Model

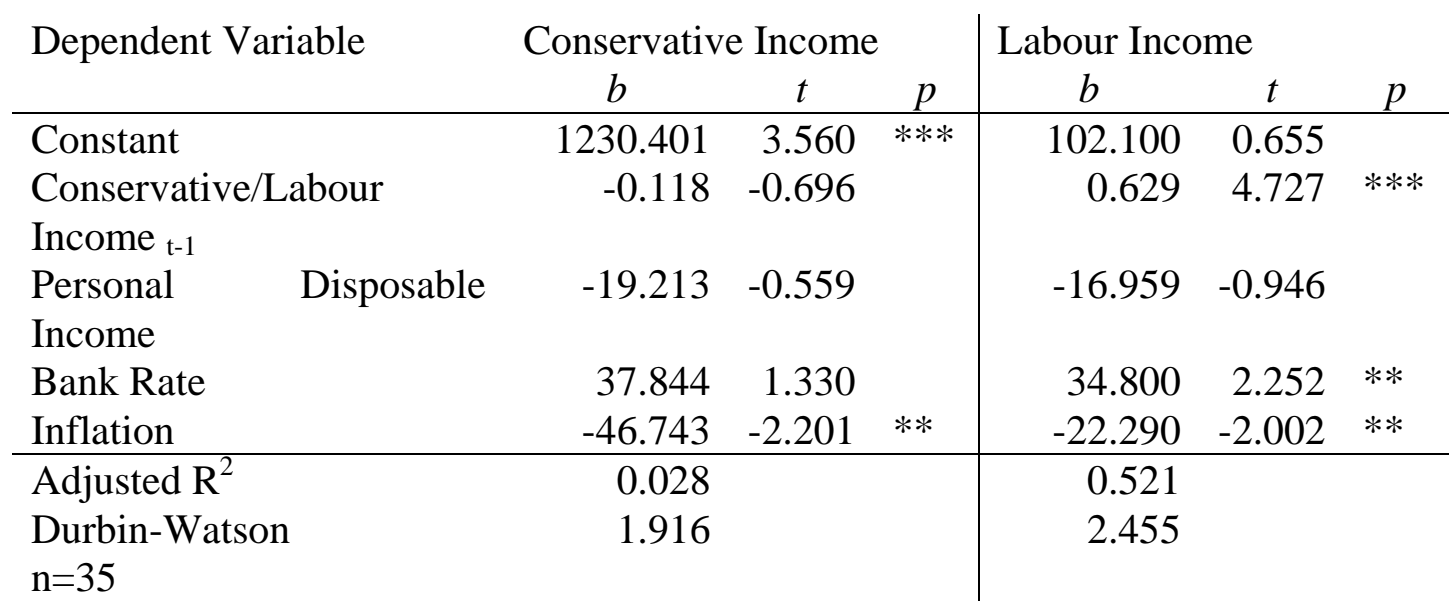

*** significant at 0.01 level

** significant at 0.05 level

* $\quad$ significant at 0.1 level 


\section{Table 7}

\section{The Electoral Necessity Model}

\begin{tabular}{lrrr|rrr} 
Dependent Variable & Conservative Income & \multicolumn{3}{|l}{ Labour Income } & \\
& \multicolumn{1}{c}{$b$} & $t$ & $p$ & \multicolumn{1}{c}{$b$} & $t$ & $p$ \\
\hline Constant & 817.443 & 3.970 & $* * *$ & -19.587 & -0.224 & \\
Conservative/Labour & -0.092 & -0.638 & & 0.816 & 8.279 & $* * *$ \\
Income t-1 & & & & & & \\
Marginality & 21.591 & 1.838 & $*$ & 3.459 & 0.645 & \\
Election Year & 652.138 & 3.723 & $* * *$ & 451.558 & 5.758 & $* * *$ \\
Pre-Election Year & 348.330 & 2.003 & $* *$ & 143.347 & 1.812 & $*$ \\
\hline Adjusted R & 0.268 & & & 0.730 & & \\
Durbin-Watson & 1.878 & & & 1.989 & & \\
n=35 & & & & & &
\end{tabular}

\footnotetext{
*** $\quad$ significant at 0.01 level

** $\quad$ significant at 0.05 level

* $\quad$ significant at 0.1 level
} 


\section{Notes}

1. Part of this article was originally presented to the American Political Science Association Annual Meeting, San Francisco, 1996. I am grateful to the British Academy and London Guildhall University for funding this research. I am also grateful to Gerry Kennally (London Guildhall University) and to Harold Clarke (University of North Texas), who provided very useful methodological advice. Finally, I would like to express my gratitude to the four anonymous referees for their perceptive and helpful comments.

2. The term 'Short' money refers to Financial Aid to Opposition Parties in the House of Commons. It is named after Edward Short, Labour Leader in the House of Commons at the time of its introduction in 1975. In 1996/7, the Labour Party received £1,530,191 under this scheme.

3. The sources for all data in these and the following figures are: Conservative Party, Fisher (1996a, 1996b), Labour Party, Pinto-Duschinsky $(1981,1985,1989)$ and Webb (1992).

4. Routine expenditure is defined as year on year expenditure concerned with the maintenance of a party's infrastructure and research. It does not include any expenditure on campaigning.

5. Certainly, previous opinion polls upon the concept of state funding for political parties have yielded generally negative responses. (Fisher, 1995a: 69; Linton, 1994: 99)

6. The sources of these data are: Annual Abstract of Statistics, Economic Trends, Conservative Party, Labour Party, Gallup, CBI, Butler \& Butler (1994), Fisher (1996a;1996b), Pinto-Duschinsky (1981; 1985; 1989a) and Webb (1992). Since the data are taken as an annual observation, incumbency is defined by the party being in government for the greater proportion of the calendar year. Two of the variables represent percentage change from the previous year rather than the level form of those variables. These were included as there is a plausible theoretical link between improvements in those variables being significant. Thus, a percentage reduction in unemployment is still likely to have an impact upon levels of income whereas the level of unemployment may not.

7. When interaction terms are used in regression analysis, problems of collinearity amongst independent variables sometimes arise. However, this was not the case in these analyses.

8. The model was also run with the CBI Industrial Trends Survey included as a predictor of Labour income. It made no discernible difference to the results of the regression 